\title{
A hatékony drogprevenció kialakításának lehetőségei Magyarországon
}

\author{
Szalay Krisztina, Antal Károly, Emri Zsuzsa \\ Eszterházy Károly Egyetem
}

\section{Bevezetés}

Az európai trendnek megfelelően Magyarországon is terjed a marihuána, a biofü, a serkentő típusú drogok fogyasztása és ezzel párhuzamban az alkoholfogyasztás és a dohányzás is, föként a fiatal fogyasztók között. Sajnos a prevenció még mindig inkább a drogok fajtáira, fogyasztásuk következményeire koncentrál a drogellenes attitűd fejlesztését szolgáló korszerű programok megvalósítása helyett. Kérdőívünkben azt vizsgáltuk, hogy a jelenlegi, ismeretátadást elötérbe helyező prevenciós programok mennyire sikeresek, mennyire pontosan adják át a függőséggel és drogfogyasztással kapcsolatos ismereteket. Átlagosabbnál tájékozottabb populációt vizsgáltunk, mivel kérdőívünket döntő részben biológia, tanító, óvodapedagógia szakos hallgatók töltötték ki. Ennek ellenére az derült ki, hogy még ebben a populációban is felszínesek az ismeretek, a függőséget okozó szerek egészségügyi és egyéb veszélyeit alábecsülik. A médiában, interneten a drogokkal kapcsolatos hírekre ugyan felfigyelnek, de ritkán jegyzik meg az ott elhangzottakat pontosan. Eredményünk összhangban van a drogprevencióval foglalkozó szakemberek véleményével, mely szerint a jelenlegi prevenció hatékonysága nem kielégítő.

\section{Drogfogyasztási attitüdök}

\section{Európa}

Európában a kábítószer-lefoglalások alapján a leggyakrabban használt drog a marihuána és származékai, arányait tekintve a lefoglalások összes mennyiségének több mint 75\%-át teszi ki. ${ }^{1}$ A kannabisz-használat prevalenciája a 15-24 éves korosztálynál 30\%. Ez azonban az európai országok átlagolt adata, 3 ország kivételével az összes ország részt vett a kutatásban, vagyis vannak olyan országok, ahol alig jellemző a drogfogyasztás, míg máshol jóval magasabb,

\footnotetext{
1 http://www.emcdda.europa.eu/system/files/publications/963/TDAT14001HUN.pdf
} 
mint 30\%. ${ }^{2}$ Az utolsó 5 évben a kannabisz-származékok fogyasztása emelkedett, míg a klasszikus drogok fogyasztása visszaesést mutat.

Magyarország

Egy 2015-ös ESPAD felmérés alapján a leggyakrabban használt kábítószer a marihuána volt hazánkban is (1. ábra). A marihuána és származékainak prevalenciája a 16 éves diákok között 18,6\% volt (Elekes, 2016). A kannabisz-származékok fogyasztása az európai trendnek megfelelően emelkedett, rögtön második helyre bekerültek az új típusú szintetikus kannabinoidok, és terjedőben vannak, ha nem is a kannabiszhoz hasonló mértékben, az amfetamin és származékai, a kokain és az LSD is (1. ábra).

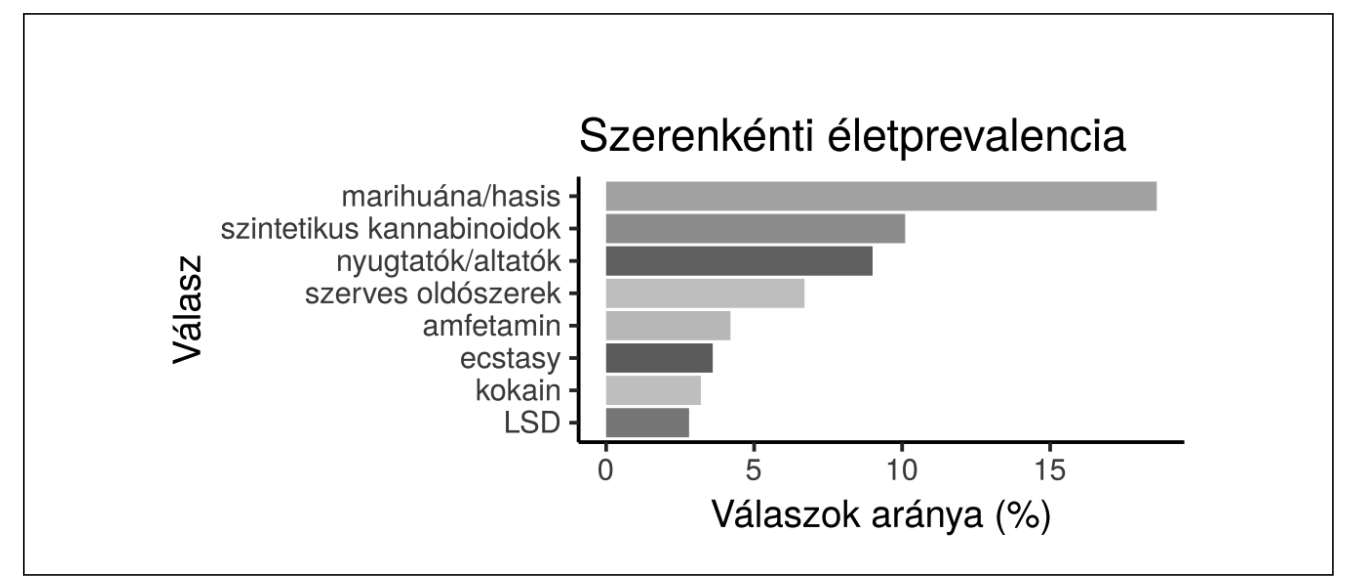

1. ábra. Szerenkénti életprevalencia-értékek a 16 éves diákok körében 2015-ben (forrás: Elekes, 2016).

\section{Prevenció}

Az EMCDDA (European Monitoring Centre for Drugs and Drug Addiction Kábítószer és Kábítószer-függőség Európai Megfigyelö Központja) javaslata alapján hazánkban is többféle prevenciót azonosíthatunk be a célcsoporttól, a prevenciós módszerektől függően. Az általános prevenció célozhatja a teljes populációt, az összes hazai lakost, de lehet behatároltabb is, például a középiskolások vagy csak néhány középiskola diákjait veszi csak célba. Az általános prevenció tehát nem tesz semmilyen különbséget az egyének között, a kiválasztott populációnak szól. A célzott prevenció esetében a populációból egy meghatározott szempont alapján veszélyeztetettnek nyilvánított egyéneket válasz-

\footnotetext{
2 http://drogfokuszpont.hu/wp-content/uploads/emcdda_ar2011_hu.pdf 
tanak ki, és a programot úgy alakítják, hogy az ennek a célcsoportnak legyen hasznos. A javallott prevenció olyan személyeknek szól, akik ugyan még nem függők, de annak korai jeleit már mutatják. ${ }^{3}$ Célkitüzéseiket tekintve a prevenciós beavatkozások sokfelé irányulhatnak, de döntő többségük, 87,5\%-uk a drogokkal kapcsolatos ismeretek átadására helyezi a hangsúlyt. A programok $\mathrm{kb}$. háromnegyede a mindennapi és/vagy szociális készségek fejlesztésével is foglalkozik, és negyedük-harmaduk fókuszál csak a visszautasítási technikák fejlesztésére. Sajnos csak a programok kis része mutat alternatívákat a droghasználatba való menekülés helyett (Paksi, Demetrovics, Nyírádi, Nádas, Buda és Felvinczi, 2006). Egy, az iskolai prevenciót vizsgáló tanulmány szerint a prevenciós szakemberek nagy részének véleménye az, hogy a közoktatási intézményekben a prevenció csak korlátozott hozzáférésü. Ennek több oka lehet, sok iskolába be sem jutnak a szakemberek, sokszor a programok sem a megfelelő színvonalúak és tartalmúak (Paksi és Magi, 2013).

\section{Kérdőívünk}

Kérdőívünben azt vizsgáltuk, hogy milyen ismeretekkel rendelkeznek a kitöltők a függőséggel kapcsolatban, mennyire hallottak a kannabisz egyéb, nem rekreációs hatásairól. A kérdőív online is elérhető volt, és az intézmény biológia, tanító és óvodapedagógia szakos diákjait külön megkértük, hogy szakítsanak időt kitöltésére. Ezeken a szakokon a függőség biológiai alapjairól, következményeiröl is tanulnak a diákok, vagyis az átlagosnál jóval tájékozottabb populációt vizsgáltunk. A kérdőívet 190-en töltötték ki, zömében egyetemisták, a kérdőív online volt kitölthető, anonim módon. A kérdések a szocioökonomikus státusz felmérése után a legális és illegális drogfogyasztási szokásokra irányultak, majd a válaszadók ismereteire voltunk kíváncsiak a drogokról, függőségröl. A kitöltők nagy része $(69,3 \%)$ nő volt, társadalmi-gazdasági státuszukat tekintve az átlagosnál jobb helyzetủek. Többé-kevésbé rendszeres dohányzásról és alkoholfogyasztásról ( $>6$ cigaretta illetve alkoholegység fogyasztása az elmúlt 30 napban) a kitöltők 28\% illetve 18\%-a számolt be, ez hasonló az országos átlaghoz gyakoriságban, de mennyiségben kedvezőbb képet mutat [http://www. espad.org/sites/espad.org/files/FULL-REPORT-Supplement-to-The-2011-ESPAD-Report-WEB.pdf]. Arra a kérdésre, hogy az elmúlt 30 napban hányszor fogyasztott alkoholt, a válaszadók közel 60\%-a 1-5 alkalomról számolt be, 15\%-uk viszont 5-30 alkalomról. Ez szintén kisebb mértékü fogyasztást mutat,

\footnotetext{
$3 \mathrm{http} / / /$ drogfokuszpont.hu/wp-content/uploads/prevencio_nemzetkozi_trendjei.pdf
} 
mint a KSH által közölt adatok, amelyben 375 ezerre becsülik az alkoholisták számát Magyarországon. ${ }^{4}$ A vizsgált populáció az illegális szerek közül jellemzően a kannabiszt próbálta ki (34\%), ezenkívül a gyógyszert alkohollal, nyugtató, altatót orvosi javallat nélkül, illetve patron, lufikéjgáz legalább egyszeri fogyasztásának gyakorisága haladta meg a 10\%-ot. A többi drog (kokain, LSD, varázsgomba, ópiátok stb.) kipróbálása elenyésző mértékủ volt. A kérdőív második részénél a függőség fogalmának ismeretét teszteltük (2. ábra).

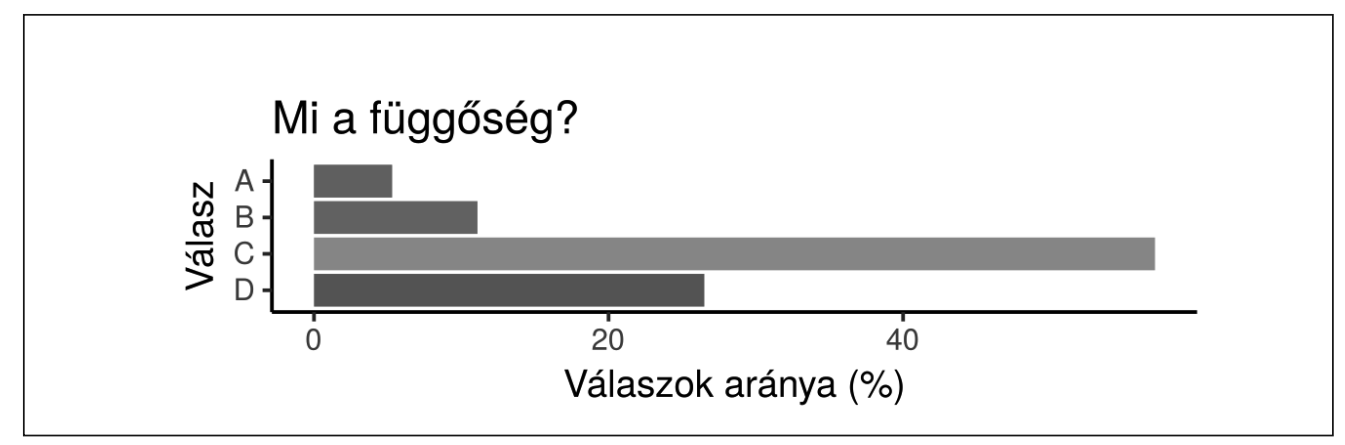

2. ábra. A válaszok százalékos megoszlása a"Mi a függőség?" kérdésre

A: Amikor valaki rendszeresen végez egy tevékenységet.

B: Amikor egy tevékenység különösen nagy örömöt okoz és igyekszünk minél többször csinálni.

C: Amikor egy tevékenységet muszáj állandóan csinálnunk, akkor is ha ez akadályozza mindennapi tevékenységeink elvégzését és jelentős anyagi terhet jelent számunkra.

D: Amikor egy tevékenységet akkor is folytatunk, ha már másra nincs is időnk, anyagi terhet jelent és érezzük egészségkárosító hatását is.

A válaszadók nagy része azzal ugyan tisztában volt, hogy a függőség negatív módon befolyásolja a függő életminőségét és jelentős anyagi teherrel jár (57\%), de csak kis részük (26\%) emelte ki a drogfogyasztás egészségkárosító hatását. Ez azt jelenti, hogy még ebben a populációban, amely tájékozottabb a témát illetően, sem tudják nagy százalékban, hogy a függőségnek nagyon komoly egészségkárosító hatása van.

Kutatási adatok szerint a hazai felnőtt populáció határozottan elutasítja a droghasználókkal való érintkezést, a kábítószer-használók jelentik az egyik legellenszenvesebb csoportot a közvélemény számára (Busa, Füzesi, Kesztyüs, Szemelyácz, és Tistyán, 2009). Nagyon elgondolkodtató, hogy a társadalom

\footnotetext{
4 http://www.ksh.hu/docs/hun/xstadat/xstadat_eves/i_fek005.html
} 
nagy része elutasító a drogfogyasztókkal szemben, ugyanakkor sokan nem tudják, hogy a drogfüggőség betegség, komoly egészségkárosító hatással.

Jellemző módon a függőség mint betegség és az egyes szerekhez történő hozzászokás lehetősége között a kitöltők nem tesznek különbséget (3. ábra).

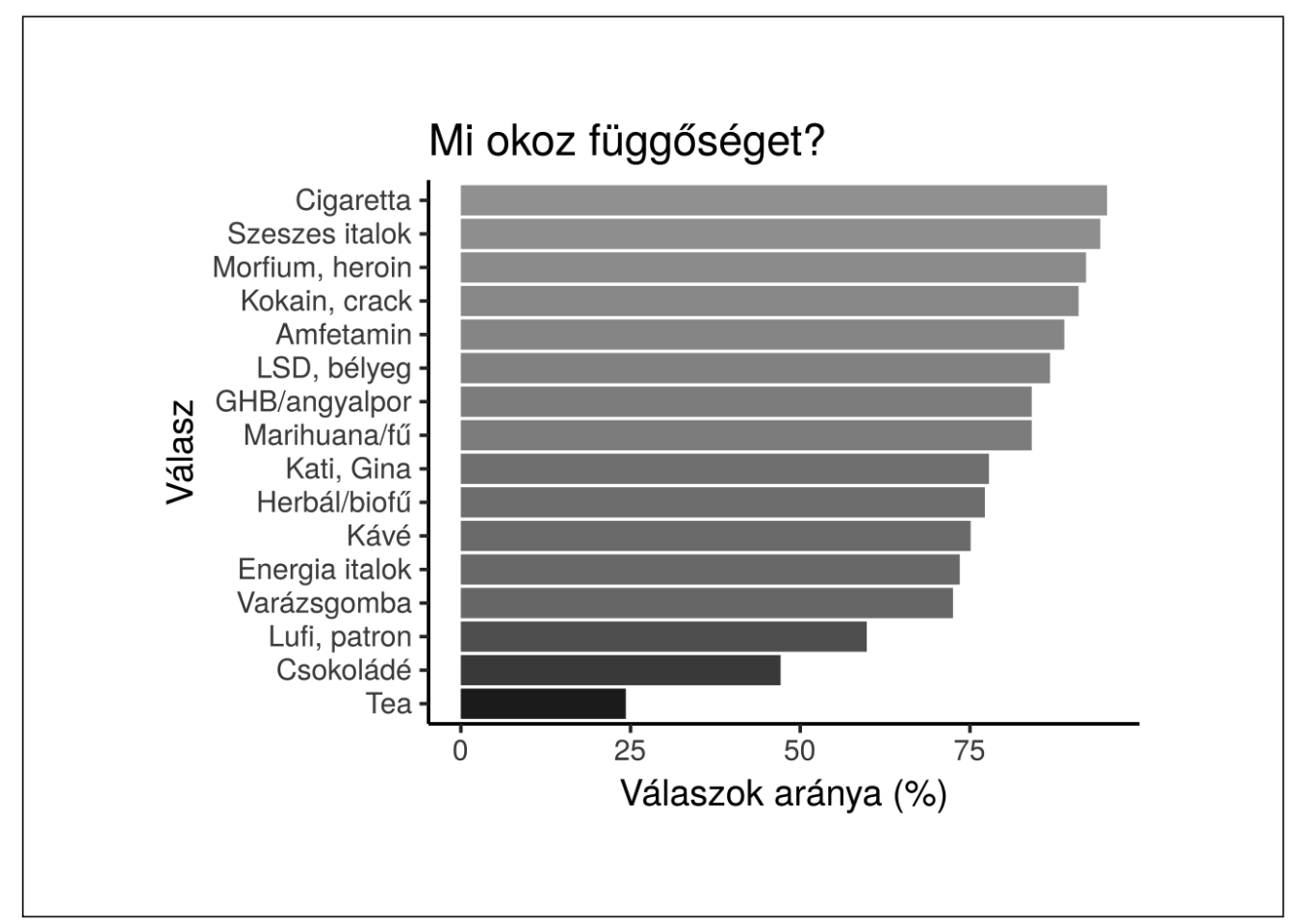

3. ábra. Az egyes anyagok emlitésének gyakorisága a függöséget okozó anyagok között

Legkevésbé a teát tartották függőséget okozó szernek a kitöltők, a kávé és az energiaitalok megítélése csaknem azonos volt a herbál/biofüvel és a varázsgombával. A cigaretta, szeszes italok, klasszikus drogok (heroin, morfium) kerültek a függőséget okozó szerek közé a kitöltők >90\%-nál, 80-90\%-uk sorolta ide a marihuánat, GHB-t LSD-t, amfetaminszármazékokat. Hasonló volt a megítélése a kávénak, energiaitaloknak, varázsgombának, mesterséges kannabinoidoknak (herbál, biofü), a klasszikus drogoknak, ha a webshopokban használatos nevükre kérdeztünk rá (Kati és Gina), a kitöltők még kisebb, csak 70-80\%-a sorolta őket a függőséget okozó szerek közé (3. ábra).

Arra a kérdésre, hogy a függőség betegség-e, a válaszadók 7,4\%-a a „nem”, ugyanennyien a „,nem tudom” választ jelölték meg. Ezek a válaszok szorosan kapcsolódnak a társadalom drogfüggőkkel szembeni határozott elutasításához. 
Jellemzően nem tudatosult az sem, hogy a függőség visszafordíthatatlan változást jelenthet a függő életében, a kitöltők majdnem 32\% azt gondolja, hogy teljes mértékben gyógyítható, illetve további $8 \%$-uk csak az arra hajlamosaknál ítélte meg nem gyógyíthatónak. A függőség kialakulását elösegítő tényezők tekintetében leginkább a szerhasználat gyakoriságát tartották a kitöltők fontosnak $(92,6 \%)$, örökletes tényezök és a környezet szerepét csak körülbelül a kitöltők fele ítélte lényegesnek (4. ábra).

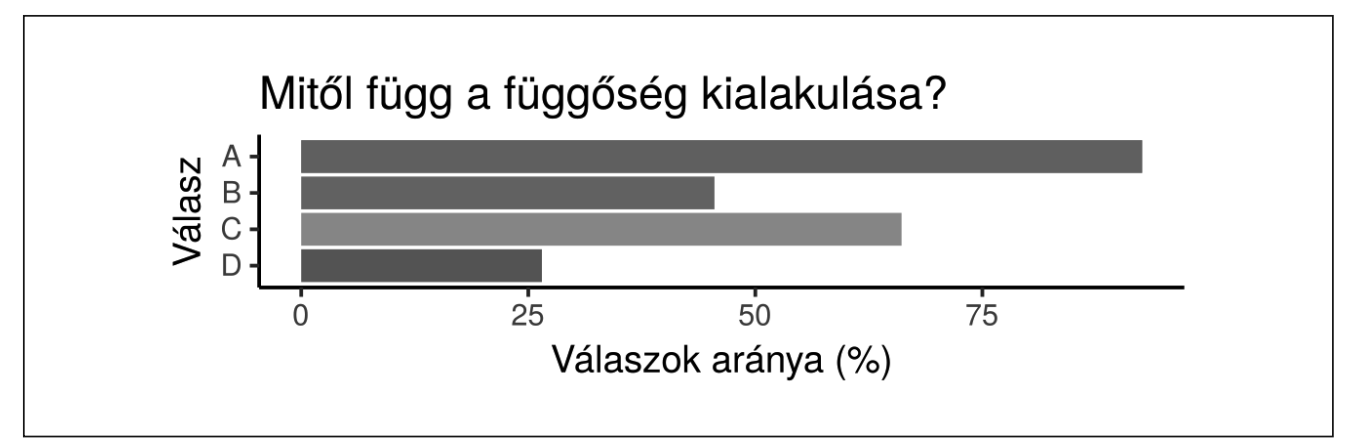

4. ábra A függőség kialakulásában szerepet játszó tényezők

A: Szertől és a használat gyakoriságától, mennyiségétől

B: Örökletes tényezőktől / hajlamtól

C: Környezeti hatásoktól

D: Egészségi állapottól

Ugyan a kitöltőknek csak 15\%-a nem sorolta a függőséget a betegségek közé, de arról hogy a függőség kialakulását jelentősen befolyásolhatják örökletes tényezők már 46\% tudott. Amikor a leginkább terjedő illegális drognak, a kannabisznak a hatásairól kérdeztünk, a megkérdezettek nagy része nem rendelkezett pontos ismeretekkel. A média kannabisszal kapcsolatos híreit valószínüleg követték, sokan hozták helyesen összefüggésbe a kannabiszt a fájdalomcsillapítással, kemoterápia mellékhatásainak enyhítésével, de 21\%-uk szerint a kannabisz alkalmas skizofrénia kezelésére, holott a skizofréniával kapcsolatban a kannabiszt mint súlyosbító tényezőt szokták emlegetni (Demetrovics és Pajkossy, 2007; Nunez és Gurpegui, 2002; Poole és Brabbins, 1996). Amikor azt kellett megjelölniük, hogy kiknek a legveszélyesebb kipróbálni a kannabiszt, szorongás, depresszió előfordulása a családban volt a leggyakoribb válasz (54\%), a skizofrénia elöfordulását jóval kevesebben (28\%) jelölték meg mint leginkább veszélyeztető tényezőt, és még a rákos betegségek családi halmozódása is 10\%-nál szerepelt veszélyeztető tényezőként. Sajnos, a válaszadók 17\%-a úgy gondolja, hogy a marihuána és a szintetikus kannabinoidok 
hatása ugyanolyan, vagyis annak ellenére, hogy a prevenciós programok nagy része leginkább drogismeretet ad, a drogfajtákról alkotott tudásuk is nagyon felületes volt a kitöltőknek. A drogot már kipróbálók kb. 27\%-a baráttól kapta vagy baráti társaságban osztozott rajta. Ez az eredmény is ugyanazt a tényt erösíti meg, mint más, hasonló témájú kutatások, vagyis a kortárscsoportok döntő szerepéhez nem fér kétség. ${ }^{5}$ Ugyanezen csoport nagy része azért próbálta ki a drogot, mert kíváncsi volt és/vagy el akart lazulni. Elgondolkodtató, hogy miért ezt a módszert választják ellazulásra.

\section{Sikeres prevenciós programok}

A hazai prevenciós programok célkitüzései a drogokkal, drogfogyasztással kapcsolatos ismeretek átadása, egészségfejlesztéssel kapcsolatos tudás fejlesztése, önismereti, visszautasítási technikák, életvezetési készségek és egyéb szociális készségek fejlesztése, alternatívák ismertetése. A programok nagy részénél a felsorolt célkitüzések átfedésben vannak, de amelyek egy célkitüzést jelölnek meg, ott nagy hányaduk a droggal kapcsolatos ismeretek átadását célozza meg. Sajnos, a programok döntő hányada rövid időintervallumú, és dominál a frontális módszer. Az iskolai prevenciós programok korszerütlenségének okai között felsorolják a forráshiányt, az iskolák alacsony prevenciós aktivitását (Paksi, Demetrovics, Nyírádi, Nádas, Buda és Felvinczi, 2006). A drogok fajtáit, hatásaikat ismertető programoknak minimális hatása van a célpopulációra (Faggiano, Vigna-Taglianti, Versino, Zambon, Borraccino, Lemma,2005, 2008; White és Pitts, 1998). Az igazi cél az lenne, hogy a fiatalok a droggal való találkozáskor képesek legyenek elutasító magatartást tanúsítani, függetlenül a helyszíntől és a kortárscsoport esetleges pozitív attitüdjétől. A droggal kapcsolatos elutasító viselkedést fejlesztő készségeiket a kortárscsoport-család-iskola-társadalom keretben kell kiépíteni (Takakura, 2011; West, 2004). A korszerü programok, módszerek még kevés országban érhetőek csak el. ${ }^{6}$ Egy több országot érintő kutatásban bizonyították az ilyen típusú prevenciós módszerek eredményességét (Cuijpers, 2002; Rooney és Murray, 1996). Átfogó kutatás keretében 7 európai ország 170 iskolájában 7079 tanulót vontak be a vizsgálatukba. A program előtt és után is végeztek vizsgálatot. Maga a program tartalmazott drogokkal kapcsolatos ismereteket, az adott ország fiataljait érintő prevalenciaadatok ismertetését, a diákok intraperszonális és interperszonális,

\footnotetext{
5 http://www.ogyei.hu/upload/files/nemzeti_jelentes_2003.pdf

6 http://www.emcdda.europa.eu/attachements.cfm/att $218446 \_E N \_T D 0113424 E N N . p d f$
} 
döntéshozó, visszautasító készségeinek, képességeinek fejlesztését, illetve különböző copingstratégiák tanítását. Ezt a klasszikus módszereken kívül szerepjátékokkal segítették. A program kezdete előtti mérésekhez képest jelentősen csökkent azon tanulók száma, akik az elmúlt 30 napban alkoholt fogyasztottak vagy kannabiszt használtak (Faggiano, Vigna-Taglianti, Versino, Zambon, Borraccino, Lemma, 2010).

\section{Összefoglalás}

Kérdőívünk válaszai azt mutatják, hogy a drogokkal kapcsolatos témát illetően még az átlagosnál jobb ismeretekkel rendelkező populáció tudása is felületes, hiányos, nem helytálló annak ellenére, hogy a prevenciós programok nagy része az információátadásra helyezi a hangsúlyt. Ebből kiindulva fokozni kellene az információátadás hatékonyságát, megbízhatóbbá kellene tenni a fiatalok droggal kapcsolatos ismereteit. A prevenciós programoknál nagyobb hatékonyságú, korszerü programokat kellene alkalmazni, melyek fejlesztik a drog elutasításával kapcsolatos készségeket, a szociális és személyes kompetenciákat, és alternatívákat ajánlanak a drogfogyasztás helyett. Ezeket a programokat minden közoktatási intézményben egységessé, elérhetővé és kötelezővé lehetne tenni.

\section{Felhasznált irodalom}

Busa Csilla - Füzesi Zsuzsanna - Kesztyüs Márk - Szemelyácz János - Tistyán László (2009): Kirekesztés és kirekesztődés - a droghasználók társadalmi megítélése. Kapocs, 8. 2. sz. 1-2.

Cuijpers, P. (2002): Effective ingredients of school-based drug prevention programs. A systematic review. Addictive Behaviors, 27. évf. 6 sz. 1009-1023.

Demetrovics Zsolt és Pajkossy Péter (2007): A kannabisz-használat szerepe a pszichotikus állapotok kialakulásában Psychiatria Hungarica, 22 2. sz. $145-162$.

Elekes Zsuzsanna (szerk.) (2016): Európai iskolavizsgálat az alkohol-és egyéb drogfogyasztási szokásokról - 2015, Magyarországi eredmények, Budapesti Corvinus Egyetem, Budapest.

Faggiano, F. - Vigna-Taglianti F. D. - Versino, E. - Zambon, A. - Borraccino, A. - Lemma, P. (2005): School-based prevention for illicit drug's use. Cochrane Database of Systematic Reviews, 2. CD003020 https://doi. org/10.1002/14651858.CD003020.pub2 
Faggiano, F. - Vigna-Taglianti, F. D. - Versino, E. - Zambon, A. - Borraccino, A. - Lemma, P. (2008): School-based prevention for illicit drugs use: a systematic review. Preventive Medicine, 46. 5. sz. 385-396. https://doi. org/10.1016/j.ypmed.2007.11.012

Faggiano, F. - Vigna-Taglianti, F. - Burkhart, G. - Bohrn, K. - Cuomo, L. Gregori, D. - Panella, M. - Scatigna, M. - Siliquini, R. - Varona, L. - van der Kreeft, P. - Vassara, M. - Wiborg, G. - Galanti, M. R. - EU-Dap Study Group (2010): The effectiveness of a school-based substance abuse prevention program: 18-Month follow-up of the EU-Dap cluster randomized controlled trial. Drug and Alcohol Dependence, 108. 1-2 sz. 56-64. https://doi. org/10.1016/j.ypmed.2008.06.018

Nunez, L. A, Gurpegui, M. (2002): Cannabis-induced psychosis: a cross-sectional comparison with acute schizophrenia. Acta Psychiatrica Scandinavica, 105. 173-178. https://doi.org/10.1034/j.1600-0447.2002.10079.x

Paksi B. - Magi A. (2013): Drogprevenciós helyzet(jelentés). Socio.hu/2013/2. 4-5.

Paksi Borbála - Demetrovics Zsolt - Nyírády Adrienn - Nádas Eszter - Buda Béla - Felvinczi Katalin (2006): A magyarországi iskolai drogprevenciós programok jellemzöi. Addiktológia, 5. 1-2. sz. 24-25.

Poole, R. - Brabbins, C. (1996): Drug induced psychosis. The British Journal of Psychiatry, 168. 135-138. https://doi.org/10.1192/bjp.168.2.135

Rooney, B. L. - Murray, D. M. (1996): A meta-analysis of smoking prevention programs after adjustment for errors in the unit of analysis. Health Education Quarterly, 23. 48-64. https://doi.org/10.1177\%2F109019819602300104

Takakura M. (2011): Does social trust at school affect students' smoking and drinking behavior in Japan? Social Science \& Medicine, 72. 299-306. https://doi.org/10.1016/j.socscimed.2010.11.003

White, D. - Pitts, M. (1998): Educating young people about drugs: a systematic review. Addiction. 93. 10 sz. 1475-1487. https://doi.org/10.1046/j.13600443.1998.931014754.x 


\section{Abstract \\ Possibilities of forming of an effective drug prevention in Hungary}

Similarly to other European countries, the use of illegal drugs, smoking, and consuming alcohol are spreading in Hungary. Unfortunately, the prevention programs focus on reviewing the types of the drugs instead of developing anti-drug attitudes. In our study, we examined the effectiveness of knowledge transmitting prevention programs. Our population is better informed like an average population but their knowledge is not appropriate and shallow. They underestimate the dangers of using drugs. Our results are in accordance with the results of professionals, who state that the efficiency of the current prevention programs is not satisfying. 